\title{
POTENSI PEWARNA DARI BIT MERAH (Beta vulgaris L.) SEBAGAI ANTIOKSIDAN
}

\section{Potential of dye from red bit (Beta vulgaris L.) as antioxidant}

\author{
Elazmanawati Lembong* dan Gemilang Lara Utama \\ Program Studi Teknologi Pangan, Departemen Teknologi Industri Pangan, Fakultas Teknologi Industri Pertanian, Universitas \\ Padjadjaran, Bandung, Indonesia \\ Doi: 10.37195/jac.v3i1.122
}

\section{*KORESPONDENSI}

Telepon: +62-852-9428-6661

E-mail: elazmanawati.lembong@unpad.ac.id

\section{JEJAK PENGIRIMAN}

Diterima: 29 Jan 2021

Revisi Akhir: 18 Feb 2021

Disetujui: 26 Feb 2021

\section{KEYWORDS}

Beetroot, Natural dyes, Antioxidant activity

\section{KATA KUNCI}

Bit merah, Pewarna alami, Aktivitas antioksidan

\section{ABSTRACT}

In this 21st century, natural dyes are starting to be reckoned with in developed countries. This is because synthetic dyes that are usually used are starting to be abandoned, in the long term they will accumulate residues in the body so that it has negative effects on health. This natural dye has two functions, namely as a dye and a source of bioactive components. One source of this natural dye is betalain from beetroot which also has antioxidant activity. This study aims to compare the color and antioxidant activity the beetroot from several solvents used. The research method used is descriptive. The solvent used in this study was ethanol with the addition of citric acid (2\%), ascorbic acid (0.05M), and tartaric acid (3\%). The brightness level of the beetroot extract from various solvents was low because the $L^{*}$ value measured using the Chromameter ranged from 5.70 to 6.01. The color of the red beetroot extract tends to be red and there is a yellowish color marked with positive $a^{*}$ and $b^{*}$ values, namely 4.36-9.02 and $0.20-2.33$. The highest antioxidant activity was beetroot extract using ethanol $+2 \%$ citric acid which was able to inhibit free radicals by $96.65 \%$ at a concentration of $2000 \mathrm{ppm}$.

Pada abad ke-21 ini, pewarna alami mulai menjadi hal yang diperhitungkan di negara-negara maju. Hal ini disebabkan pewarna sintetik yang biasanya digunakan mulai ditinggalkan, dalam jangka waktu yang panjang akan mengakumulasi residu dalam tubuh sehingga memberikan efek negatif bagi kesehatan. Pewarna alami ini mempunyai dua fungsi yaitu sebagai pewarna dan sumber komponen bioaktif. Salah satu sumber pewarna alami ini adalah betalain dari umbi bit merah yang juga memiliki aktivitas antioksidan. Penelitian ini bertujuan untuk membandingkan warna dan aktivitas antioksidan umbi bit merah dari beberapa pelarut yang digunakan. Metode penelitian yang digunakan adalah deskriptif. Pelarut yang digunakan dalam penelitian ini adalah pelarut etanol dengan tambahan asam sitrat (2\%), asam askorbat $(0,05 \mathrm{M})$ dan asam tartrat (3\%). Tingkat kecerahan dari ekstrak umbi bit merah dari berbagai pelarut rendah karena nilai $L^{*}$ yang diukur menggunakan Chromameter berkisar antara 5,70-6,01. Warna ekstrak umbi bit merah ini cenderung merah dan ada warna kekuningan ditandai dengan nilai $a^{*}$ positif dan $b^{*}$ positif yaitu 4,36-9,02 dan 0,20-2,33. Aktivitas antioksidan yang paling tinggi adalah ekstrak umbi bit merah menggunakan etanol + asam sitrat $2 \%$ yang mampu menghambat radikal bebas sebesar 96,65\% pada konsentrasi 2000 ppm. 


\section{PENDAHULUAN}

Warna merupakan salah satu daya tarik dalam pangan sehingga bahan pewarna ini menjadi salah satu bahan tambahan pangan. Bahan pewarna yang digunakan bisa alami maupun sintetis. Pewarna sintetis cenderung menjadi pilihan karena pewarna alami memiliki kekurangan yaitu tidak dapat mempertahankan warna dalam waktu yang lama. Penggunaan pewarna sintetis mengalami perkembangan yang cukup pesat sehingga banyak oknum yang menyalahgunakannya. Salah satu penyalahgunaan tersebut adalah menggunakan pewarna sintetis yang bukan untuk makanan dikarenakan harganya lebih murah dibandingkan pewarna sintetis untuk makanan. Hal ini berbahaya karena pewarna sintetis tersebut memiliki sifat karsinogenik dimana dalam jangka panjang dapat membahayakan kesehatan manusia. Oleh karena itu kita perlu mencari sumber-sumber pewarna makanan alami yang aman dan harganya murah.

Umbi bit merah merupakan salah satu bahan pangan yang bermanfaat sebagai pewarna alami dalam pembuatan produk makanan. Senyawa betasianin yang terkandung dalam umbi bit merah ini berbeda dengan pigmen antosianin pada tanaman lain karena mengandung senyawa nitrogen yang mempunyai efek positif terhadap aktivitas radikal bebas dan kanker. Winanti, Andriani, \& Nurhartadi (2013) mulai mengembangkan umbi bit merah ini sebagai alternatif pewarna alami pada produk sosis. Hal ini sejalan dengan pendapat Tesoriere, Allegra, Gentile, \& Livrea (2009), dimana betasianin mempunyai fungsi sebagai antioksidan alami selain sebagai pewarna.

Betasianin adalah salah satu pigmen yang bisa digunakan sebagai pewarna alami dengan cara diekstrak dari tumbuhan. Betasianin ini mempunyai sifat mudah larut dalam air, sehingga sangat baik untuk dikembangkan sebagai pewarna alami. Menurut Strack, Vogt, \& Schliemann (2003), betasianin terdapat pada bagian bunga, buah dan daun yang memiliki warna merah keunguan pada tumbuhan. Suhu, $\mathrm{pH}$, cahaya, oksigen dan ion logam berpengaruh terhadap kestabilan dan sensitivitas betasianin (Herbach, Stintzing, \& Carle, 2006).

Penggunaan betasianin sebagai bahan pewarna alami adalah bentuk ekstraknya. Menurut Azeredo (2009), ekstraksi betasianin dapat dilakukan menggunakan pelarut akuades, metanol dan etanol. Penelitian yang dilakukan oleh Castellar, Obón, Alacid, \& Fernández-López (2003), yaitu proses ekstraksi betasianin dari buah Opuntia menggunakan pelarut akuades dan campuran akuades : etanol dimana hasilnya didapatkan total betasianin yang lebih tinggi menggunakan pelarut akuades. Hasil penelitian Maia dalam Azeredo (2009), penggunaan pelarut etanol-asam klorida (99:1) memberikan total betasianin yang lebih tinggi dibandingkan dengan pelarut akuades. Hal ini sejalan dengan Strack et al. (2003) dimana ekstraksi betasianin dengan kondisi yang sedikit asam dalam larutan akuades memberikan kestabilan pada senyawa betasianin.

Dari berbagai sumber di atas, maka pada penelitian ini, dilakukan ekstraksi betasianin dari umbi bit merah menggunakan pelarut etanol dengan penambahan asam sitrat (2\%), asam askorbat $(0,05 \mathrm{M})$ dan asam tartarat (3\%). Ekstrak betasianin yang diperoleh akan dilakukan perbandingan warna dan aktivitas antioksidan dengan penambahan berbagai asam tersebut.

\section{BAHAN DAN METODE}

\section{Bahan}

Bahan-bahan penelitian ini adalah umbi bit merah diperoleh dari petani di daerah Parung, Kota Bogor, etanol (70\%) diproduksi oleh Sigma Aldrich United States, asam sitrat, asam askorbat, dan asam tartarat ketiganya diproduksi oleh Merck Germany.

\section{Desain Penelitian}

Tahapan penelitian ini dimulai dengan mengekstrak pigmen betasianin dari umbi bit merah menggunakan berbagai macam pelarut yaitu:

$\mathrm{A}=$ Pelarut etanol dengan tambahan asam sitrat (2\%),

$\mathrm{B}=$ Pelarut etanol dengan tambahan asam askorbat $(0,05 \mathrm{M})$ dan 
$C=$ Pelarut etanol dengan tambahan asam tartarat (3\%).

Parameter yang diamati adalah intensitas warna dengan alat kromameter dan aktivitas antioksidan.

\section{Ekstraksi Bit Merah (Sari, Hudha, \& Prihanta, 2016)}

Ekstraksi dilakukan secara maserasi menggunakan pelarut sesuai perlakuan selama 24 jam pada suhu ruang, kedap udara, dan kedap cahaya. Perbandingan bahan dengan pelarut adalah 1:10 (b/v). Hasil ekstraksi disaring menggunakan kertas saring dan didapatkan filtrat yang telah terpisah dari ampas. Filtrat dipekatkan menggunakan rotary evaporator pada suhu $40{ }^{\circ} \mathrm{C}$. Ekstrak pekat disimpan pada botol gelap bertutup di dalam refrigerator.

\section{Metode Analisis}

Pengujian Warna. Pengujian warna ekstrak bit merah dilakukan dengan alat kromameter menggunakan sistem pengukuran CIE $\mathrm{L}^{*} \mathrm{a}^{*} \mathrm{~b}^{*}$. Alat khromameter dikalibrasi terlebih dahulu kemudian mengatur menu kromameter untuk menggunakan skala pengukuran $\mathrm{L}$, a, dan $\mathrm{b}$. Selanjutnya dilakukan pengukuran warna sampel, dan mengamati hasil pengukuran di bagian data processor. Data yang didapat berupa nilai $L^{*}, a^{*}$, dan $b^{*}$. Nilai $L^{*}$ menunjukkan Light/terang, $a^{*}$ menunjukkan koordinat merah/hijau, dan $\mathrm{b}^{*}$ menunjukkan koordinat kuning/biru. Nilai $L^{*}$ yang semakin tinggi menyatakan semakin terang warna suatu sampel. Sebaliknya, nilai L* yang semakin rendah menyatakan semakin gelap warna sampel. Semakin tinggi nilai $\mathrm{a}^{*}$ menyatakan warna sampel semakin mendekati warna merah, semakin rendah nilai a* menyatakan warna sampel semakin mendekati warna hijau. Semakin tinggi nilai $\mathrm{b}^{*}$ menyatakan warna sampel semakin mendekati warna kuning dan semakin rendah nilai $b^{*}$ menyatakan warna sampel semakin mendekati warna biru.

Selanjutnya dilakukan perhitungan nilai HUE dengan mengonversi nilai $L^{*} a^{*} b^{*}$ untuk menentukan daerah kisaran warna kromatisitas menggunakan rumus berikut:

$$
\text { HUE }=\tan -1(b / a)
$$

Aktivitas Antioksidan. Metode DPPH (1,1difenil-2-pikrildidrazil) merupakan suatu metode kolometri yang efektif dan cepat untuk memperkirakan aktivitas antiradikal. DPPH ini merupakan suatu radikal stabil yang mengandung nitrogen organik, mempunyai warna ungu gelap dan absorbansinya kuat pada $\lambda$ maksimal $517 \mathrm{~nm}$. Setelah bereaksi dengan antioksidan maka warna larutan akan berkurang dan akan berubah menjadi kuning dimana perubahan warna ini diukur menggunakan spektrofotometer (Prakash, Rigelhof, \& Miller, 2001).

Aktivitas antioksidan dapat didefinisikan sebagai kuantitas hidrogen dari senyawa antioksidan yang diikat oleh DPPH, dimana hasil ini dinyatakan dengan nilai persentase (\%) inhibisi (Windono, Hendrajaya, Nurfatmawati, \& Soraya, 2001). Persentase inhibisi dapat menunjukkan nilai $\mathrm{IC}_{50}$ (Inhibition Concentration 50\%), ini merupakan konsentrasi larutan sampel yang akan menyebabkan reduksi terhadap aktivitas DPPH sebesar $50 \%$. Nilai $I_{50}$ dihitung dari persentase penghambatan serapan larutan ekstrak menggunakan persamaan yang diperoleh dari kurva regresi linier. Menurut Molyneux (2004), semakin tinggi nilai $\mathrm{IC}_{50}$ semakin rendah aktivitas antioksidannya, dan semakin rendah nilai $\mathrm{IC}_{50}$ semakin tinggi aktivitas antioksidannya.

\section{HASIL DAN PEMBAHASAN \\ Pengujian Warna Ekstrak Bit Merah}

Pigmen warna pada umbi bit merah berbeda dengan tanaman berwarna lain, dimana pigmen warna merahnya berasal dari antosianin. Di dalam umbi bit merah terkandung pigmen betalain yang merupakan kombinasi dari betasianin, pigmen berwarna ungu dan betaxantin, pigmen berwarna kuning. Hasil dari penelitian Jastrebova, Witthöft, Grahn, Svensson, \& Jägerstad (2003) dan Kujala, Vienol, Klika, Loponen, \& Pihlaja (2002) didapatkan umbi bit merah mengandung senyawa antioksidan yaitu polifenol dan juga asam folat. Betalain dari umbi bit merah menunjukkan sifat antiradikal dan antioksidan yang tinggi dari penelitian uji in vitro yang dilakukan Pedreño \& Escribano (2000), Kanner, Harel, \& Granit (2001) dan Wettasinghe, Bolling, Plhak, \& Parkin (2002).

Warna dari betasianin adalah merah atau merah-violet dan merupakan salah satu pewarna alami yang telah banyak digunakan 
dalam produk pangan. Sampai kini, pigmen betasianin yang diproduksi dalam jumlah besar berasal dari umbi bit merah. Dari penelitian Mastuti, Cai, \& Corke (2010), betasianin yang diperoleh dari umbi bit merah memiliki efek antiradikal dan aktivitas antioksidan yang tinggi.

Pengujian warna ekstrak bit merah dilakukan dengan alat kromameter menggunakan sistem pengukuran CIE L* $a^{*} b^{*}$. Pengujian ini bertujuan untuk mengetahui perbedaan warna antara ekstrak bit merah sesuai dengan perlakuan pada penelitian ini. Selain itu, melalui pengujian warna dapat diketahui bahan pangan yang memiliki kesamaan jenis warna dengan ekstrak bit merah sehingga dapat diaplikasikan sebagai bahan pengawet alami dengan tepat. Prinsip pengujian ini berdasarkan teori warna yang menyatakan sebuah warna tidak bisa merah dan hijau serta kuning dan biru secara bersamaan. Warna $\left(L^{*}, a^{*}\right.$, dan $\left.b^{*}\right)$ ekstrak bit merah pada berbagai konsentrasi ditampilkan pada Tabel 1.

Tabel 1. Warna $\left(L^{*} a^{*} b^{*}\right)$ dan ${ }^{\circ}$ Hue ekstrak bit merah pada berbagai konsentrasi

\begin{tabular}{lcccccc}
\hline \multirow{2}{*}{ Perlakuan } & \multicolumn{3}{c}{ Warna } & \multirow{2}{*}{${ }^{\circ}$ Hue } & Kisaran Warna \\
\cline { 2 - 4 } & $\mathbf{L}^{*}$ & $\mathbf{a}^{*}$ & $\mathbf{b}^{*}$ & & \\
\hline $\mathrm{A}$ = Pelarut etanol + asam sitrat $[2 \%]$ & 6,01 & 9,02 & 2,33 & 14,48 & Red Purple \\
\hline $\mathrm{B}$ = Pelarut etanol + asam askorbat $[0,05 \mathrm{M}]$ & 5,70 & 4,36 & 0,28 & 3,67 & Red Purple \\
\hline $\mathrm{C}$ = Pelarut etanol + asam tartarat $[3 \%]$ & 5,72 & 4,87 & 0,20 & 2,35 & Red Purple \\
\hline
\end{tabular}

Nilai L* (kecerahan) menyatakan cahaya pantul yang menghasilkan warna akromatik putih, abu-abu, dan hitam. Semakin tinggi nilai L* hingga batas nilai 100, maka kecerahan semakin maksimal dan sebaliknya semakin rendah nilai $\mathrm{L}^{*}$ hingga mendekati nilai 0 maka kecerahannya semakin gelap. Nilai $a^{*}$ (kemerahan) positif menunjukkan warna kromatik merah, sedangkan nilai a* negatif maka warna menunjukkan warna kromatik hijau. Nilai $b^{*}$ (kekuning-kuningan) positif menunjukkan warna kromatik kuning, sedangkan nilai $b^{*}$ negatif menunjukkan warna kromatik biru (Khrisna \& Khanta, 2005).

Ekstrak umbi bit merah dengan pelarut etanol cenderung menghasilkan tingkat kecerahan yang rendah yaitu antara 5,70-6,01. Ekstrak umbi bit merah ini memiliki tingkat kecerahan yang rendah bahkan mendekati gelap. Pengamatan selanjutnya yaitu pengamatan warna $a^{*}$ menunjukkan nilai positif antara 4,36-9,02 yang artinya ekstrak umbi bit merah memiliki warna kemerahan walaupun tidak dominan. Pengamatan warna $\mathrm{b}^{*}$ (kekuningan) ekstrak umbi bit merah menunjukkan nilai postitif 0,20-2,33 yang artinya memiliki warna kekuningan walaupun intesitasnya kecil. Pengujian warna ini sesuai dengan penelitian Jastrebova et al. (2003) dan Kujala et al. (2002) bahwa pigmen yang mempengaruhi warna merah pada umbi bit adalah pigmen betalain yang merupakan kombinasi dari pigmen ungu betasianin dan pigmen kuning betaxantin.

Hasil pengujian warna menunjukkan ekstrak bit merah dengan pelarut etanol ditambah asam askorbat $(0,05 \mathrm{M})$ mempunyai warna paling gelap dan paling kurang merah dibandingkan ekstrak bit merah lainnya yang ditandai dengan nilai $\mathrm{L}^{*}$ dan $a^{*}$ paling kecil, serta berada pada daerah kisaran warna Red Purple (RP) berdasarkan nilai ${ }^{\circ}$ Hue. Warna yang lebih gelap disebabkan karena ekstrak bit merah melalui proses pemekatan sehingga warna ekstrak menjadi lebih gelap. Sementara itu, ekstrak bit merah dengan pelarut etanol ditambah asam sitrat (2\%) memiliki warna paling terang dan paling merah dibandingkan ekstrak dengan penambahan asam lainnya. Ekstrak umbi bit merah dengan penambahan asam tartarat (3\%) berwarna paling biru sebab memiliki nilai $b^{*}$ terkecil dibandingkan ekstrak dengan penambahan asam lainnya dan berada pada daerah kisaran warna RP berdasarkan nilai ${ }^{\circ}$ Hue.

Ekstrak umbi bit merah dengan penambahan asam sitrat (2\%) memiliki nilai $L^{*}, a^{*}$, dan $b^{*}$ yang lebih tinggi dibandingkan ekstrak dengan penambahan asam lainnya yang berarti memiliki warna lebih cerah, lebih merah, dan lebih kuning, serta berada pada daerah kisaran warna RP berdasarkan nilai 
${ }^{\circ}$ Hue. Perbedaan warna ekstrak bit merah dengan penambahan asam disajikan dalam Gbr. 1.

\section{Aktivitas Antioksidan Ekstrak Bit Merah}

Berdasarkan hasil penelitian Mastuti et al. (2010) yang mendapatkan kandungan aktivitas antioksidan yang tinggi, penelitian ini dilakukan dengan membandingkan aktivitas antioksidan ekstrak umbi bit merah menggunakan pelarut etanol : asam sitrat $2 \%$; etanol : asam askorbat 0,05 $\mathrm{M}$ dan etanol : asam tartarat 3\%. Metode yang digunakan dalam menguji kandungan aktivitas antioksidan dari bit merah ini adalah metode $\mathrm{DPPH}$

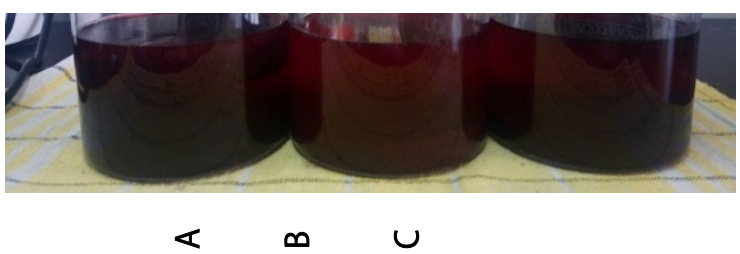

Gbr. 1. Warna ekstrak bit merah $(A=$ etanol + asam sitrat $2 \%, B=$ etanol + asam askorbat $0,05 \mathrm{M}, \mathrm{C}=$ etanol + asam tartarat 3\%)

Prinsip pengukuran aktivitas antioksidan metode DPPH adalah mengukur terjadinya pemudaran warna radikal DPPH disebabkan adanya antioksidan yang menetralkan molekul radikal bebas. Dalam hal ini, radikal DPPH yang awalnya berwarna akan kehilangan warna jika ada antioksidan, dikarenakan antioksidan akan menyumbangkan elektronnya kepada radikal DPPH. Radikal yang sebelumnya tidak stabil akibat adanya elektron yang tidak berpasangan karena mendapat sumbangan elektron dari antioksidan. Karakteristik antioksidan pada dasarnya mudah menyumbangkan elektron, jika semakin mudah memberikan elektron maka sifat antioksidannya semakin kuat.

Pengujian aktivitas antioksidan dalam penelitian ini menggunakan panjang gelombang maksimum $517 \mathrm{~nm}$. Pengujian aktivitas antioksidan menggunakan larutan 3 mg ekstrak bit merah dalam $1 \mathrm{~mL}$ metanol. Dalam pengujian DPPH, suatu senyawa dikatakan memiliki aktivitas antioksidan sangat kuat jika nilai $\mathrm{IC}_{50}$ kurang dari $50 \mathrm{ppm}$, dikatakan kuat jika nilai $\mathrm{IC}_{50}$ antara $50-100$ ppm, dikatakan sedang jika nilai $\mathrm{IC}_{50}$ 101-150 ppm, dan dikatakan lemah jika nilai IC $C_{50}$ antara 150-200 ppm (Molyneux, 2004).
Berdasarkan hasil uji aktivitas antioksidan ekstrak umbi bit merah dengan etanol + asam sitrat $2 \%$ didapatkan rata-rata $\mathrm{IC}_{50}$ aktivitas antioksidannya adalah 412,54 ppm dapat dikatakan lemah (Molyneux, 2004). Dari Gbr. 2 terlihat bahwa semakin tinggi konsentrasi inhibitor (ppm) ekstrak umbi bit merah, semakin tinggi \% inhibisinya (menghambatnya). Hubungan ini sangat erat yaitu dengan $r^{2}$ sebesar 0,9939 artinya 99,39\% konsentrasi ekstrak umbi bit merah mempengaruhi persen penghambatannya terhadap radikal bebas. Sehingga dapat dikatakan pada konsentrasi 2000 ppm, ekstrak umbi bit merah menghambat radikal bebas sebesar $96,65 \%$.

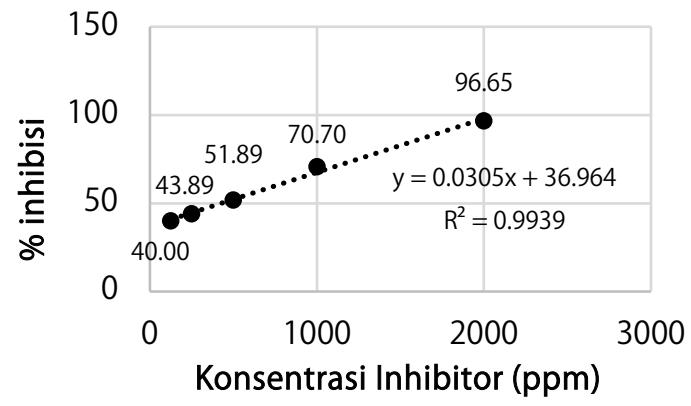

Gbr. 2. Kurva \% inhibisi ekstrak beet lokal etanol + asam sitrat $2 \%$

Berdasarkan hasil uji aktivitas antioksidan ekstrak umbi bit merah dengan etanol + asam tartarat 3\% didapatkan rata-rata $\mathrm{I} C_{50}$ aktivitas antioksidannya adalah 1541,93 ppm dikatakan sangat lemah (Molyneux, 2004). Dari Gbr. 3 terlihat bahwa semakin tinggi konsentrasi inhibitor (ppm) ekstrak umbi bit merah, semaikin tinggi \% inhibisinya (menghambatnya). Hubungan ini sangat erat yaitu dengan $r^{2}$ sebesar $\quad 0,9997$ artinya 99,97\% konsentrasi ekstrak umbi bit merah mempengaruhi persen penghambatannya terhadap radikal bebas. Sehingga dapat dikatakan pada konsentrasi 2000 ppm, ekstrak umbi bit merah menghambat radikal bebas sebesar $63,14 \%$ lebih rendah dibandingkan dengan persen penghambatan menggunakan etanol : asam sitrat $2 \%$.

Berdasarkan hasil uji aktivitas antioksidan ekstrak umbi bit merah dengan etanol + asam tartarat $3 \%$ didapatkan rata-rata $\mathrm{IC}_{50}$ aktivitas antioksidannya adalah 729,08 ppm dapat dikatakan lemah (Molyneux, 2004). Dari Gbr. 4 terlihat bahwa semakin tinggi konsentrasi 
inhibitor (ppm) ekstrak umbi bit merah, semaikin tinggi \% inhibisinya (menghambatnya). Hubungan ini sangat erat yaitu dengan $r^{2}$ sebesar 0,9951 artinya 99,951\% konsentrasi ekstrak umbi bit merah mempengaruhi persen penghambatannya terhadap radikal bebas. Sehingga dapat dikatakan pada konsentrasi 2000 ppm, ekstrak umbi bit merah menghambat radikal bebas sebesar 67,78\% lebih rendah dibandingkan dengan persen penghambatan menggunakan etanol + asam sitrat $2 \%$ tetapi lebih tinggi dibandingkan menggunakan etanol + asam tartarat 3\%.

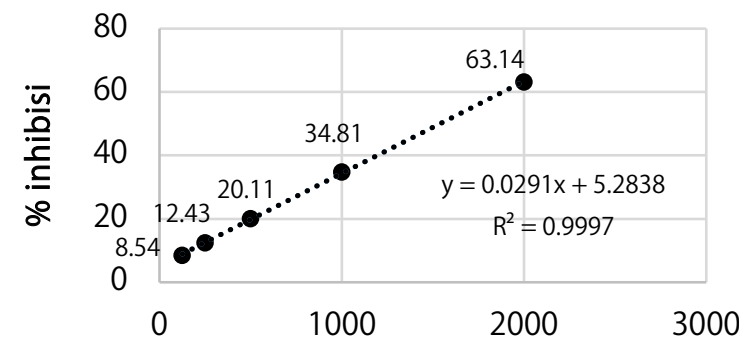

Konsentrasi Inhibitor (ppm)

Gbr. 3. Kurva \% inhibisi esktrak bit lokal etanol + asam tartarat $3 \%$

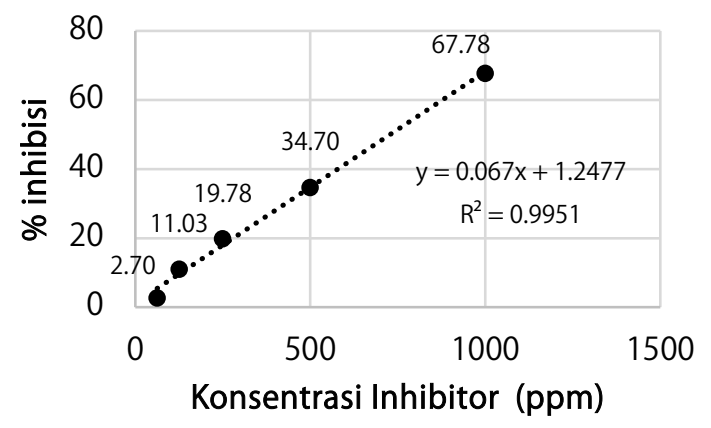

Gbr. 4. Kurva \% inhibisi esktrak bit lokal etanol + asam askorbat 0,05 $\mathrm{M}$

Betasianin dalam umbi bit merah memiliki fungsi sebagai pewarna dan juga sebagai antioksidan alami (Tesoriere et al., 2009). Nilai aktivitas ketiga ekstrak bit merah tergolong pada aktivitas antioksidan lemah dan sangat lemah. Rendahnya nilai aktivitas antioksidan ini dapat disebabkan oleh perlakuan ekstraksi sampel yang cukup sederhana (menggunakan metanol) sehingga betasianin dalam umbi bit merah, tidak stabil ketika dilakukan pengujian antioksidan.

Kapasitas antioksidan bit merah dari berbagai kultivar (7 macam kultivar yang dipanen oleh CV. Czerwona Kula Polandia tahun 2002) berdasarkan penelitian Janusz Czapski, Mikołajczyk, \& Kaczmarek (2009) diperoleh kapasitas antioksidan yang berkisar antara 10,2-21,7 $\mu \mathrm{mol}$ Trolox.mL $\mathrm{mL}^{-1}$; kapasitas antioksidan yang diperoleh dalam penelitian tersebut menggunakan metode yang berbeda dengan penelitian ini yaitu menggunakan Trolox Equivalent Antioxidant Capacity (TEAC) assay. Perbedaan yang cukup jauh ini dapat disebabkan oleh perbedaan kultivar dan metode ektraksi yang digunakan serta metode pengujian antioksidannya. Dari hasil penelitian Czapski et al. (2009) diperoleh kapasitas antioksidan yang cukup tinggi dari bit merah, tetapi dalam penelitian ini untuk ekstrak embi bit merah menggunakan etanol + asam sitrat pada konsentrasi 2000 ppm, mampu menghambat radikal bebas sebesar $96,65 \%$.

\section{KESIMPULAN}

Kesimpulan pada penelitian ini adalah ekstrak umbi bit merah dengan pelarut etanol ditambah asam sitrat $2 \%$ mempunyai warna lebih terang karena memiliki $\mathrm{L}^{*}, \mathrm{a}^{*}$, dan $\mathrm{b}^{*}$ yang lebih tinggi dari ekstrak umbi bit merah dengan pelarut etanol ditambah asam lainnya dan menghasilkan aktivitas antioksidan tertinggi, dimana pada konsentrasi 2000 ppm, mampu menghambat radikal bebas sebesar $96,65 \%$, sehingga dapat dikatakan umbi bit merah ini mempunyai potensi sebagai pewarna alami yang mengandung antioksidan.

\section{PENGHARGAAN}

Penulis menghaturkan terima kasih kepada Rektor Universitas Padjadjaran yang telah membiayai penelitian ini melalui skema Riset Fundamental Universitas Padjadjaran (RFU) Tahun Anggaran 2018.

\section{DAFTAR PUSTAKA}

Azeredo, H. M. C. (2008). Betalains: properties, sources, applications, and stability - a review. International Journal of Food Science \& Technology, 44(12), 2365-2376. doi:10.1111/j.1365-2621.2007.0166 8.x

Castellar, R., Obón, J. M., Alacid, M., \& Fernández-López, J. A. (2003). Color Properties and Stability of Betacyanins fromOpuntiaFruits. Journal of Agricultural and Food Chemistry, 51(9), 2772-2776. doi:10.1021/jf021045h 
Czapski J., Mikołajczyk, K., \& Kaczmarek, M. (2009). Relationship between antioxidant capacity of red beet juice and contents of its betalain pigments. Pol. J. Food Nutr. Sci., 59(2), 119-122.

Herbach, K. M., Stintzing, F. C., \& Carle, R. (2006). Betalain stability and degradation structural and chromatic aspects. Journal of Food Science, 71(4), R41-R50. doi:10.1111/j.1750-3841.2006.00022.x

Jastrebova, J., Witthöft, C., Grahn, A., Svensson, U., \& Jägerstad, M. (2003). HPLC determination of folates in raw and processed beetroots. Food Chemistry, 80(4), 579-588. doi:10.1016/s0308-8146(02)005 06-x

Kanner, J., Harel, S., \& Granit, R. (2001). Betalains - a new class of dietary cationized antioxidants. Journal of Agricultural and Food Chemistry, 49(11), 5178-5185. doi:10.1021/jf010456f

Khrisna, M. \& Kantha, H. I. (2005). Food colour measurement: instrumentation and techniques. Journal Instrum Soc. Indian, 35 (2), 227-238.

Kujala, T., Vienola, M., Klika, K., Loponen, J., \& Pihlaja, K. (2002). Betalain and phenolic compositions of four beetroot (Beta vulgaris) cultivars. European Food Research and Technology, 214(6), 505-510. doi:10.1007/s00217-001-0478-6

Mastuti, R., Cai, Y., \& Corke, H. (2010). Identifikasi pigmen betasianin pada beberapa jenis Inflorescence Celosia. Paper dipresentasikan di Seminar Nasional Biologi, Yogyakarta, Indonesia.

Molyneux, P. (2004). The use of the stable free radical diphenylpicrylhydrazyl (DPPH) for estimating antioxidant activity. Songklanakarin Journal of Science and Technology (SJST), 26, 211-219.

Pedreño, M. A., \& Escribano, J. (2000). Studying the oxidation and the antiradical activity of betalain from beetroot. Journal of Biological Education, 35(1), 49-51. doi:10.1080/00219266.2000.9655736

Prakash, A., Rigelhof, F., \& Miller, E. (2001). Antioxidant activity. Medallion Laboratories Analytical Progress, 19.

Sari, N. M. I., Hudha, A. M., \& Prihanta, W. (2016). Uji kadar betasianin pada buah bit (Beta vulgaris L.) dengan pelarut etanol dan pengembangannya sebagai sumber belajar biologi. Jurnal Pendidikan Biologi Indonesia, 2(1), 72-77.

Strack, D., Vogt, T., \& Schliemann, W. (2003). Recent advances in betalain research. Phytochemistry, 62(3), 247-269. doi:10.1016/s0031-9422(02)00564-2

Tesoriere, L., Allegra, M., Gentile, C., \& Livrea, M. A. (2009). Betacyanins as phenol antioxidants. Chemistry and mechanistic aspects of the lipoperoxyl radicalscavenging activity in solution and liposomes. Free Radical Research, 43(8), 706-717. doi:10.1080/107157609030376 81

Wettasinghe, M., Bolling, B., Plhak, L., \& Parkin, K. (2002). Screening for Phase II Enzyme-inducing and Antioxidant Activities of Common Vegetables. Journal of Food Science, 67(7), 2583-2588. doi:10.1111/j.1365-2621.2002.tb08781.x

Winanti, E. R., Andriani, M. A. M., \& Nurhartadi, E. (2013). The effect of addition beet (Beta vulgaris) as a natural dye on physicochemical and sensory characteristics in beef sausage. Jurnal Taksonomi Pangan, 2(4), 18-24.

Windono, T., Hendrajaya, K., Nurfatmawati, H., \& Soraya, F. (2001). Uji peredaman radikal bebas terhadap DPPH dari ekstrak kulit buah dan biji anggur probolinggo biru dan bali. Artikel hasil penelitian Artocarpus, 1 , 34-43. 